\title{
FLYPAPER EFFECT ATAS DANA ALOKASI UMUM DAN PENDAPATAN ASLI DAERAH TERHADAP BELANJA MODAL KABUPATEN/KOTA DI PROVINSI MALUKU UTARA
}

\author{
Jesiska C Karwur $^{1}$, Ventje Ilat ${ }^{2}$, Jessy D.L Warongan ${ }^{3}$ \\ ${ }^{1,2,3}$ Jurusan Akuntansi, Fakultas Ekonomi dan Bisnis, Universitas Sam Ratulangi, Jl. Kampus Bahu, Manado, \\ 95115, Indonesia \\ E-mail: jesiskakarwur1@gmail.com
}

\begin{abstract}
This research is aimed examine whether the General Allocation Fund and Regional Real Income effect the Capital Expenditure Regrency/City in the Province of North Maluku and to analyze the possibility of the accurrence of flypaper effect to the Capital Expenditure of Regrency/City in the Province of North Maluku in 2014-2016. The Population of this research is report on realization of regional budjet and expenditure budjet (APBD) Regrency/City in the area of North Maluku Province. This sample use with method pusposive sampling and the number of samples are 30 data. The data that was used are secondary datas which has been obtained from the report on realization of regional budjet and expenditure budjet (APBD) Regrency/City in the Province of North Maluku from 2014 to 2016 which have been obtained from Badan Pusat Statistik (BPS) Maluku Utara. The data analysis instrument that was use in this research is the multiple linear analysis. The results shows that : 1) The General Allocation Fund has significant influence to the Capital Expenditure Regrency /City in the Province of North Maluku. 2) The Regional Real Income fund has no significant influence to the Capital Expenditure Regrency/City in the Province of North Maluku. 3) The flypaper effect has occurred on capital expenditure of Regrency/City in the Province of North Maluku.
\end{abstract}

Keywords: General Allocation Fund (DAU), Regional Real Income (PAD), flypaper effect

\section{PENDAHULUAN}

Negara Indonesia merupakan salah satu negara berkembang yang menggunakan model sistem desentralisasi. Dengan sistem desentralisasi, Pemerintah Pusat menyerahkan wewenang pemerintahan kepada suatu daerah untuk mengatur urusan pemerintahan di derahnya sendiri. Wewenang daerah yang diterima dari Pemerintah Pusat itu disebut otonomi daerah. Pelaksanaan Otonomi Daerah di Indonesia, dimulai secara efektif tanggal 1 Januari 2001. Dalam Undang-Undang Nomor 32 Tahun 2004 dinyatakan bahwa untuk pelaksanaan kewenangan pemerintah daerah, pemerintah pusat akan mentransfer dana perimbangan yang terdiri dari Dana Alokasi Umum (DAU), Dana Alokasi Khusus (DAK), dan bagian daerah dari Dana Bagi Hasil (DBH) yang terdiri dari pajak dan sumber daya alam. Selain dana perimbangan dari pemerintah pusat tersebut, pemerintah daerah mempunyai sumber pendanaan sendiri berupa Pendapatan Asli Daerah (PAD), pembiayaan dan lain-lain pendapatan. Namun dalam kenyataannya, transfer dari pemerintah pusat merupakan sumber dana utama pemerintah daerah untuk membiayai operasi utamanya sehari-hari yang oleh pemerintah daerah dilaporkan sebagai bagian dari Anggaran Pendapatan dan Belanja Daerah (APBD).

Disisi lain dapat dilihat bahwa pendapatan asli daerah lumayan banyak, tapi sepertinya pemerintah daerah tidak konsisten dalam menggunakan dana tersebut. Dana sebagian yang seharusnya digunakan untuk memenuhi belanja modal lebih banyak berharap 
dan bergantung pada dana transfer dari pemerintah pusat yaitu Dana Alokasi Umum. Sehingga besar kemungkinan untuk terjadinya Flypaper Effect. Halim (2002) dan Sukriy (2003) melakukan penelitian adanya flypaper effect pada Belanja Daerah pemerintah Kabupaten/Kota di Pulau Jawa dan Bali pada tahun 2001. Dari penelitian tersebut diperoleh kesimpulan bahwa flypaper effect terjadi pada Dana Alokasi Umum (DAU) periode t-1 terhadap Belanja Daerah (BD) periode t, kemudian Maimunah (2006) melakukan penelitian yang sama pada pemerintah daerah Kabupaten/Kota di Pulau Sumatera pada tahun 2003 dan 2004. Kusumadewi dan Rahman (2007) melakukan penelitian pada Kota dan Kabupaten di Indonesia.

Hasil yang diperoleh konsisten dengan penelitian Halim (2002) dan Abdullah (2003) yaitu Dana Alokasi Umum (DAU) pada periode t-1 memiliki pengaruh lebih besar dari pada Pendapatan Asli Daerah (PAD) periode t-1 terhadap Belanja Daerah (BD) periode t. Namun ketika diuji pengaruh Dana Alokasi Umum (DAUt) dan Pendapatan Asli Daerah (PADt) secara bersama sama terhadap Belanja Daerah t, hasilnya Pendapatan Asli Daerah (PAD) tidak signifikan dan Dana Alokasi Umum (DAU) berpengaruh terhadap Belanja Daerah (BD). Hasil penelitian tersebut tidak dapat digeneralisasi untuk daerah lainnya, karena tiap daerah mempunyai karakteristik tersendiri baik dari sisi geografis, kehidupan masyarakat maupun kondisi ekonominya.

\section{TINJAUAN PUSTAKA}

\subsection{Akuntansi}

Akuntansi adalah suatu seni untuk mengumpulkan, mengidentifikasikan, mengklasifikasikan, mencatat transaksi serta kejadian yang berhubungan dengan keuangan, sihingga dapat menghasilkan informasi yaitu laporan keuangan yang dapat digunakan oleh pihak-pihak yang berkepentingan (Sumarsan,2013:1).

\subsection{Akuntansi Pemerintahan}

Akuntansi pemerintahan adalah akuntansi lembaga-lembaga nonprofit atau institusional accounting, mengkhususkan pada masalah pencatatan dan pelaporan transaksi dari unit-unit pemerintah dan organisasi non profit lainnya, seperti: Masjid, lembaga amal, yayasan, rumah sakit dan lembaga-lembaga pendidikan (Sadeli, 2015:6).

\subsection{Anggaran Pendapatan dan Belanja Daerah (APBD)}

Anggaran pendapatan dan belanja daerah (APBD) adalah daftar yang memuat rincian penerimaan daerah dan pengeluaran/belanja selama 1 tahun yang ditetapkan dengan peraturan daerah (Perda) untuk masa satu tahun, yang pelaksanaannya dimulai dari tanggal 1 januari sampai dengan tanggal 31 desember (Mahsun dkk, 2015:81).

\subsection{Otonomi Daerah}

Otonomi daerah adalah hak, wewenang dan kewajiban daerah otonom untuk mengatur dan mengurus sendiri urusan pemerintahan dan kepentingan masyarakat setempat. Dengan adanya otonomi daerah maka urusan yang menjadi hak dan tanggung jawab daerah meningkat. Untuk itu diperlukan sumber daya, termasuk sumber daya keuangan. Konsekuensi logis dari pemberian kewenangan adalah pemberian sumber daya untuk melaksanakan kewenangan tersebut (Siregar,2017:73).

\subsection{Belanja Modal}

Pada Lampiran Peraturan Menteri Keuangan Nomor 91/PMK.05/2007 Tentang Bagan Akun Standar menyebutkan Belanja Modal merupakan pengeluaran anggaran yang digunakan dalam rangka memperoleh atau menambah aset tetap dan aset lainnya yang manfaatnya lebih dari satu periode akuntansi serta melebihi batasan minimal kapitalisasi aset tetap atau aset lainnya yang ditetapkan oleh pemerintah. 


\subsection{Pendapatan Asli Daerah}

Dalam Undang-undang Nomor 33 Tahun 2004 Pasal 1 Ayat 18 menyebutkan Pendapatan Asli daerah, selanjutnya disebut PAD adalah pendapatan yang diperoleh daerah yang dipungut berdasarkan peraturan daerah sesuai dengan peraturan perundang-undangan.

\subsection{Dana Alokasi Umum}

Menurut PP Nomor 55 Tahun 2005 dan UU No.33 Tahun 2004, Dana Alokasi Umum (DAU) adalah dana yang berasal dari APBN yang dialokasikan dengan tujuan pemerataan keuangan antar daerah untuk membiayai kebutuhan pengeluaran dalam rangka pelaksanaan desentralisasi.

\subsection{Flypaper effect}

Istilah Flypaper Effect muncul karena adanya penyimpangan dalam teori bantuan pemerintah tak bersyarat bahwa transfer pemerintah pusat memang meningkatkan pengeluaran konsumsi barang publik, tetapi ternyata tidak menjadi substitut bagi pajak daerah. Fenomena tersebut yang kemudian dalam banyak literatur disebut dengan Flypaper Effect. Sedangkan istilah Flypaper Effect sendiri timbul dari pemikiran Okun (1930) dalam Kurnia (2013:4) yang menyatakan "money sticks where it hits". Sejauh ini, belum ada padanan kata "Flypaper Effect" dalam bahasa Indonesia sehingga kata ini dituliskan sebagaimana adanya tanpa diterjemahkan. Oates (1999:1120) menyatakan ketika respon Pemerintah Daerah lebih besar untuk transfer dibanding Pendapatan Asli Daerah (PAD) daerahnya sendiri maka disebut dengan Flypaper Effect.

\section{METODE PENELITIAN}

\subsection{Jenis dan Sumber Data}

Dalam penelitian ini menggunakan data kuantitatif yang berupa Jumlah Dana Alokasi Umum, Pendapatan Asli Daerah, dan Belanja Modal. Sumber data yang digunakan adalah data sekunder. Data diperoleh dari Badan Pusat Statistik (BPS) Provinsi Maluku Utara berupa data laporan Realisasi Anggaran Pendapatan dan Belanja Daerah (APBD) Kabupaten/Kota di Provinsi Maluku Utara tahun 2014-2016.

\subsection{Sampel dan Teknik Pengambilan Sampel}

Sampel dalam penelitian ini ditentukan menggunakan teknik Purposive Sampling, yaitu populasi yang akan dijadikan sampel penelitian adalah yang memenuhi kriteria/pertimbangan sampel tertentu. Adapun kriteria tersebut sebagai berikut.

a. Pemerintah Kabupaten/Kota yang menyampaikan laporan Realisasi APBD tahun 2014-2016 kepada Badan Pusat Statistik (BPS) Provinsi Maluku Utara

b. Pemerintah Kabupaten/Kota yang mendapatkan Dana Alokasi Umum dari tahun 2014-2016.

c. Pemerintah Kabupaten/Kota yang tidak dimekarkan pada kurun waktu 2014-2016.

Berdasarkan kriteria dalam penentuan sampel tersebut diperoleh jumlah Kabupaten/Kota yang layak dijadikan sampel dalam penelitian ini adalah 10 Kabupaten/Kota. Berikut tabel penentuan pengambilan sampel. 
Tabel 3.1 Penentuan Pengambilan Sampel

\begin{tabular}{|c|l|c|}
\hline No & \multicolumn{1}{|c|}{ Penentuan Sampel } & Jumlah \\
\hline 1 & $\begin{array}{l}\text { Kabupaten/Kota yang menyampaikan } \\
\text { Laporan Realisasi APBD }\end{array}$ & 10 \\
\hline 2 & $\begin{array}{l}\text { Kabupaten/Kota yang tidak menyampaikan } \\
\text { laporan Realisasi APBD kepada Badan Pusat } \\
\text { Statistik Provinsi Maluku Utara berturut-turut } \\
\text { tahun 2014-2016 }\end{array}$ & - \\
\hline 3 & $\begin{array}{l}\text { Kabupaten/Kota yang tidak mendapatkan } \\
\text { Dana Alokasi Umum dari tahun 2014-2016 }\end{array}$ & - \\
\hline 4 & $\begin{array}{l}\text { Kabupaten/Kota yang dimekarkan pada } \\
\text { kurun waktu 2014-2016. }\end{array}$ & 10 \\
\hline & $\begin{array}{l}\text { Jumlah Sampel Kabupaten/Kota yang } \\
\text { dapat digunakan }\end{array}$ & \\
\hline
\end{tabular}

Berdasarkan tabel 3.1 terdapat 10 Kabupaten/Kota yang layak dijadikan sampel penelitian dengan masing-masing data realisasi APBD Kabupaten/Kota di Provinsi Maluku Utara pada tahun 2014-2016. Dimana jumlah data tersebut diperoleh dengan rumus :

$\mathrm{N}=$ Jumlah Kabupaten/Kota $\mathrm{x}$ Periode Penelitian (Tahun)

$\mathrm{N}=10 \times 3$

$\mathrm{N}=30$

\subsection{Metode Analisis}

Analisis data berisi pengujian data yang diperoleh dari laporan Realisasi Anggaran Pendapatan dan Belanja Daerah (APBD) yaitu Dana Alokasi Umum, Pendapatan Asli Daerah, dan Belanja Modal. Analisis data yang digunakan dalam penelitian ini adalah sebagai berikut.

\section{Uji Asumsi Klasik}

Pengujian regresi dapat dilakukan setelah model dari penelitian ini memenuhi syarat uji asumsi klasik. Dengan adanya pengujian ini diharapkan agar model regresi yang diperoleh dapat dipertanggungjawabkan. Oleh karena itu, perlu dilakukan uji asumsi klasik yang terdiri dari uji normalitas, uji multikolinearitas, uji heteroskedastisitas, dan uji autokorelas sebelum melakukan uji regresi dan uji hipotesis. Berikut ini penjelasan uji asumsi klasik yang akan digunakan dalam penelitian ini.

a. Uji Normalitas

Uji normalitas bertujuan untuk mengetahui apakah data pada persamaan regresi yang dihasilkan berdistribusi normal atau berdistribusi tidak normal. (Ghozali, 2016:154). Model regresi yang baik adalah data normal atau mendekati normal. Uji normalitas yang digunakan adalah uji Kolmogorov- Smirnov. Pengambilan keputusan bisa dilakukan berdasarkan probabilitas (Asymtotic Significance), yaitu:

a) Jika probabilitas $>0,05$ maka distribusi dari populasi adalah normal.

b) Jika probabilitas < 0,05 maka populasi tdak berdistribusi secara normal.

b. Uji Multikolonieritas

Uji mulikolinearitas bertujuan untuk menguji apakah pada model regresi ditemukan adanya korelasi antar variabel bebas (independen), model regresi yang baik tidak terjadi korelasi di antara variabel independen, jika variabel independen saling berkorelasi, maka variabel-variabel ini tidak ortogonal. Untuk mengetahui atau melihat ada atau tidak multikolinieritas di dalam model regresi adalah dengan cara melihat nilai tolerance dan nilai variace inflation factor (VIF). 
a) Jika nilai Tolerance $>0,1$ dan nilai VIF $<10$, berarti tidak ada multikolinearitas antar variabel independen dalam suatu model regresi.

b) Jika nilai Tolerance $<0,1$ dan nilai VIF $>10$, berarti terjadi multikolinearitas antar variabel independen dalam suatu model regresi.

c. Uji Heteroskedastisitas

Model regresi yang baik adalah apabila terdapat kesamaan atau tidak terjadi heteroskedastisitas. Dalam penelitian ini, uji heteroskedastisitas menggunakan uji glejser. Pengujian ini dilakukan dengan meregresi nilai absolut residual terhadap variabel independen. Uji ini terlihat dari probabilitas signifikansinya di atas tingkat kepercayaan 5\% atau nilai signifikansi variabel independen $>0,05$ sehingga disimpulkan tidak terjadi heteroskedastisitas pada model regresi.

d. Uji Autokorelasi

Model regresi yang baik adalah yang tidak terjadi autokorelasi. Autokorelasi dalam suatu linear dapat mengganggu suatu model karena akan menyebabkan kebiasan pada kesimpulan yang diambil. Autokorelasi biasanya ditemukan atau dilihat pada data runtut waktu (time series) karena gangguan pada seorang individu atau kelompok cenderung menpengaruhi gangguan pada individu atau kelompok yang sama pada periode berikutnya. Dalam penelitian ini, uji autokorelasi menggunakan uji Durbin Watson (DW-Test), dimana dalam pengambilan keputusan melihat berapa jumlah sampel yang diteliti yang kemudian dilihat angka ketentuannya pada tabel Durbin Watson. Nilai Durbin Watson (DW) harus dihitung terlebih dahulu, kemudian dibandingkan dengan nilai batas atas (dU) dan nilai batas bawah (dL) untuk berbagai nilai n (jumlah sampel) dan k (jumlah variabel bebas) yang ada di dalam table Durbin Watson dengan ketentuan sebagai berikut:

A) DW $<$ dL, terdapat autokorelasi positif $(+)$

B) $\mathrm{dL}<\mathrm{DW}<\mathrm{dU}$, tidak dapat disimpulkan

C) dU $<$ DW $<4$-dU, tidak terjadi autokorelasi

D) 4-dU < DW < 4-dL, tidak dapat disimpulkan

E) $\mathrm{dW}<4-\mathrm{dL}$, terdapat autokorelasi negatif (-)

\section{Uji Regresi Linear Berganda}

Menurut Sugiyono (2016) Analisis regresi linier berganda digunakan untuk meramalkan bagaimana keadaan (naik turunnya) variabel dependen, jika dua atau lebih variabel independen sebagai faktor yang dapat dinaikturunkan nilainya. Analisis regresi linear berganda adalah untuk mengestimasikan besarnya koefisien-koefisien yang dihasilkan oleh yang bersifat linear yang melibatkan dua atau lebih variabel independen untuk digunakan sebagai alat prediksi besarnya nilai variabel dependen. Model regresi yang digunakan dapat dirumuskan dengan persamaan sebagai berikut:

$\mathrm{Y}=\alpha+\beta 1 \mathrm{X} 1+\beta 2 \mathrm{X} 2+\mathrm{e}$

Keterangan:

Y : Belanja Modal

$\alpha \quad$ : Konstanta

$\beta \quad$ : Koefisien regresi

X1 : Dana Alokasi Umum

X2 : Pendapatan Asli Daerah

e : Standart error

\section{Koefisien Determinasi $\left(\mathbf{R}^{2}\right)$}

Uji R2 yaitu untuk mengukur seberapa jauh besar kemampuan model dalam menerangkan variasi variabel dependen. Nilai koefisien determinasi adalah antara nol dan satu. Apabila kemampuan variabel independen dalam menjalaskan variasi variabel dependen amat terbatas, berarti nilai R2 nilainya kecil. Jika hanya terdapat satu variabel independen 
maka $\mathrm{R}^{2}$ yang dipakai. Tetapi apabila terdapat dua atau lebih variabel independen maka Adjusted $\mathrm{R}^{2}$ yang digunakan, setiap tambahan suatu variabel bebas, maka $\mathrm{R}^{2}$ pasti meningkat, sedangkan nilai Adjusted $\mathrm{R}^{2}$ dapat naik atau turun apabila satu variabel independen ditambahkan ke dalam suatu model. Bila terdapat nilai adjusted $\mathrm{R}^{2}$ bernilai negatif, maka nilai adjusted $\mathrm{R}^{2}$ dianggap bernilai nol.

4. Uji Hipotesis

a. $\quad$ Uji F (Uji Simultan)

Menurut Ghozali (2016:96) Uji F disini bertujuan untuk mengetahui apakah variabel bebas (independen) secara bersama-sama berpengaruh terhadap variabel terikat (dependen). Pengujian dilakukan dengan membandingkan F-hitung dengan F-tabel. Pengambilan kesimpulan hipotesis diterima atau ditolak ditentukan dengan kriteria sebagai berikut:

a) Tingkat sig $\mathrm{F} \leq 0,05$ maka hipotesis diterima, artinya variabel independen secara bersama-sama (simultan) berpengaruh terhadap variabel dependen.

b) Tingkat sig $\mathrm{F} \geq 0,05$ maka hipotesis ditolak, artinya variabel independen secara bersama-sama (simultan) tidak berpengaruh terhadap variabel dependen.

b. Uji t (Uji Parsial)

Uji t yaitu untuk menunjukkan seberapa besar pengaruh antar satu variabel bebas secara individual dalam menerangkan variabel terikat. Uji t digunakan untuk menguji hipotesis secara parsial dari variabel bebasnya. Pengujian ini dilakukan dengan cara membandingkan t-hitung dengan t-tabel. Pengambilan kesimpulan hipotesis diterima atau ditolak ditentukan dengan kriteria sebagai berikut:

a) Tingkat sig $\mathrm{t} \leq 0,05$ maka hipotesis penelitian diterima, artinya secara parsial variabel independen berpengaruh terhadap variabel dependen.

b) Tingkat sig $\mathrm{t} \geq 0,05$ maka hipotesis penelitian ditolak, artinya secara parsial variabel independen tidak berpengaruh terhadap variabel dependen.

\section{HASIL ANALISIS DAN PEMBAHASAN}

4.1. Hasil analisis
1. Uji Asumsi Klasik
a. Uji Normalitas

Tabel 4.1

Uji Normalitas

One-Sample Kolmogorov-Smirnov Test

\begin{tabular}{|ll|r|}
\hline & & \multicolumn{2}{l|}{$\begin{array}{l}\text { Unstandardized } \\
\text { Residual }\end{array}$} \\
\hline Normal Parameters & & 30 \\
& & .0000000 \\
Most Extreme Differences & Mean & Std. Deviation \\
& Absolute & .139 \\
& Positive & .139 \\
Test Statistic & Negative & -.109 \\
Asymp. Sig. (2-tailed) & & .139 \\
\hline
\end{tabular}

a. Test distribution is Normal.

b. Calculated from data.

c. Lilliefors Significance Correction.

Sumber : Olah Data SPSS

Berdasarkan hasil uji normalitas diperoleh nilai signifikan sebesar 0,144 (Asymp. Sig. (2-tailed)) dimana 0,144>0,05 maka dapat disimpulkan data berdistribusi normal. 
b. Uji Multikolinearitas

Tabel 4.2

Uji Multikolinearitas

\begin{tabular}{|ll|r|r|}
\hline \multirow{2}{*}{ Model } & \multicolumn{2}{|c|}{ Collinearity Statistics } \\
\cline { 2 - 4 } & \multicolumn{2}{|c|}{ Tolerance } & \multicolumn{1}{c|}{ VIF } \\
\hline 1 & (Constant) & .861 & 1.161 \\
& DAU & .861 & 1.161 \\
\hline
\end{tabular}

a. Dependent Variable: BM

Sumber : Olah Data SPSS

Berdasarkan hasil uji multikolinearitas diperoleh Dana Alokasi Umum nilai tolerance $0,861>0,1$ dan nilai VIF 1,161 < 10, dan Pendapatan Asli Daerah nilai tolerance 0,861 > 0,1 dan nilai VIF $1,161<10$. Jadi dapat disimpukan bahwa tidak ada multikolineritas antara variabel independen dalam model regresi karena semua variabel independen memiliki nilai tolerance $>0,1$ dan nilai $\mathrm{VIF}<10$.

c. Uji Heteroskedastisitas

Tabel 4.3

Uji Glejser

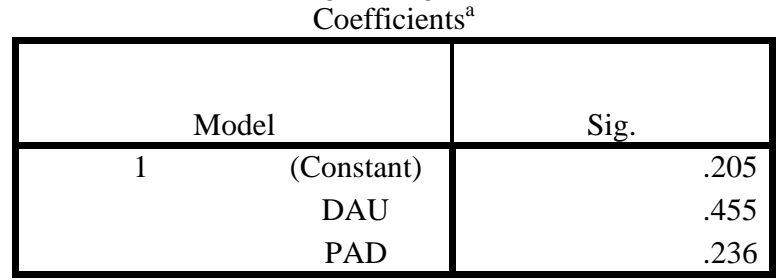

a. Dependent Variable: BM (RES2)

Sumber : Olah Data SPSS

Berdasarkan hasil uji glesjer diperoleh Dana Alokasi Umum nilai signifikansi 0,455 > 0,05 dan Pendapatan Asli Daerah nilai signifikansi 0,236>0,05. Jadi dapat disimpukan bahwa tidak terjadi masalah heteroskedastisitas pada model regresi karena signifikansi (sig.) semua variabel independen $>0,05$.

d. Uji Autokorelasi

Tabel 4.4

Uji Durbin Watson

\begin{tabular}{|c|r|r|r|r|r|}
\hline $\begin{array}{c}\text { Mode } \\
1\end{array}$ & $\mathrm{R}$ & R Square & $\begin{array}{c}\text { Adjusted R } \\
\text { Square }\end{array}$ & $\begin{array}{c}\text { Std. Error of the } \\
\text { Estimate }\end{array}$ & Durbin-Watson \\
\hline 1 & $.235^{\mathrm{a}}$ & .055 & -.015 & 37088227.39825 & 1.787 \\
\hline
\end{tabular}

a. Predictors: (Constant), PAD, DAU

b. Dependent Variable: BM (RES2)

Sumber : Olah Data SPSS

Berdasarkan hasil uji autokorelasi diperoleh nilai DW 1,787 maka nilai 1,650 < 1,787 $<2,35$. Jadi dapat disimpukan bahwa tidak terjadi autokorelasi karena $\mathrm{dU}<\mathrm{DW}<4$-dU. 


\section{Uji Regresi Linear Berganda}

Tabel 4.5

Uji Regresi Linear Berganda

Coefficients $^{a}$

\begin{tabular}{|c|c|c|c|c|c|c|}
\hline \multirow{2}{*}{\multicolumn{2}{|c|}{ Model }} & \multicolumn{2}{|c|}{ Unstandardized Coefficients } & $\begin{array}{l}\text { Standardized } \\
\text { Coefficients }\end{array}$ & \multirow[b]{2}{*}{$\mathrm{t}$} & \multirow[b]{2}{*}{ Sig. } \\
\hline & & $\mathrm{B}$ & Std. Error & Beta & & \\
\hline \multirow[t]{3}{*}{1} & (Constant) & 74977788.060 & 52920782.077 & & 1.417 & .168 \\
\hline & DAU & .330 & .123 & .496 & 2.692 & .012 \\
\hline & PAD & -.425 & .394 & -.199 & -1.079 & .290 \\
\hline
\end{tabular}

a. Dependent Variable: BM

Sumber : Olah Data SPSS

Dari Tabel 4.9 dapat diperoleh persamaan regresi linier berganda sebagai berikut:

$\mathrm{BM}=\mathbf{7 4 9 7 7 7 8 , 0 6 0}+\mathbf{0 , 3 3 0} \mathrm{X}_{1}-\mathbf{0 , 4 2 5} \mathrm{X}_{2}$.

\section{Koefisien Determinasi $\left(\mathbf{R}^{2}\right)$}

Tabel 4.6
Koefisien Determinasi
Model Summary

Sumber : Olah Data SPSS

Dari hasil pengolahan data dengan metode regresi linear berganda, diperoleh hasil koefisien determinasi berdasarkan nilai adjusted yaitu sebesar 0,153. Jadi kemampuan variabel independen yaitu Dana Alokasi Umum dan Pendapatan Asli Daerah dalam menjelaskan variasi dari variabel dependen yaitu Belanja Modal sebesar 15,3\% sedangkan sisanya sebesar $84,7 \%$ dijelaskan oleh faktor-faktor lain yang tidak diikut sertakan dalam penelitian ini.

\section{Uji Hipotesis}

\section{a. Uji F (Uji Simultan)}

\section{Tabel 4.11 Uji F}

ANOVA $^{\mathrm{a}}$

\begin{tabular}{|c|c|c|c|c|c|}
\hline Model & Sum of Squares & df & Mean Square & $\mathrm{F}$ & Sig. \\
\hline 1 Regression & $\begin{array}{r}32351984332724 \\
192.000\end{array}$ & 2 & $\begin{array}{r}16175992166362 \\
096.000\end{array}$ & \multirow[t]{3}{*}{3.628} & \multirow[t]{3}{*}{$.040^{\mathrm{b}}$} \\
\hline Residual & $\begin{array}{r}12038563618024 \\
9056.000\end{array}$ & 27 & $\begin{array}{r}44587272659351 \\
50.000\end{array}$ & & \\
\hline Total & $\begin{array}{r}15273762051297 \\
3248.000\end{array}$ & 29 & & & \\
\hline
\end{tabular}

\section{Sumber : Olah Data SPSS}

Berdasarkan hasil analisis regresi secara simultan, maka diperoleh nilai $\boldsymbol{F}_{\text {-hitung }}$ sebesar 3,628 $>\boldsymbol{F}_{\text {-tabel }}$ sebesar 2,92 dan nilai signifikansi 0,040 $<0,05$; hal ini berarti $\boldsymbol{F}_{\text {-hitung }}$ $>\boldsymbol{F}_{\text {-tabel }}$ dan tingkat signifikansi $<0,05$. 
Dengan demikian dapat dikemukakan bahwa Dana Alokasi Umum dan Pendapatan Asli Daerah secara bersama-sama berpengaruh signifikan terhadap Belanja Modal. karena $\boldsymbol{F}$. hitung $>\boldsymbol{F}$-tabel dan tingkat signifikansi $<0,05$.

\section{b. Uji t (Uji Parsial)}

Tabel 4.12 Uji t

Coefficients

\begin{tabular}{|c|c|c|c|c|c|c|}
\hline & \multirow[b]{2}{*}{ Model } & \multicolumn{2}{|c|}{ Unstandardized Coefficients } & $\begin{array}{l}\text { Standardized } \\
\text { Coefficients }\end{array}$ & \multirow[b]{2}{*}{$\mathrm{t}$} & \multirow[b]{2}{*}{ Sig. } \\
\hline & & $\mathrm{B}$ & Std. Error & Beta & & \\
\hline \multirow[t]{3}{*}{1} & (Constant) & 74977788.060 & 52920782.077 & & 1.417 & .168 \\
\hline & DAU & .330 & .123 & .496 & 2.692 & .012 \\
\hline & PAD & -.425 & .394 & -.199 & -1.079 & .290 \\
\hline
\end{tabular}

a. Dependent Variable: BM

Sumber : Olah Data SPSS

Berdasarkan hasil analisis regresi secara parsial, maka diperoleh Dana Alokasi Umum memiliki nilai $\boldsymbol{t}_{\text {-hitung }}$ sebesar 2,692 $>\boldsymbol{t}_{\text {-tabel }}$ sebesar 2,054 dan nilai signifikansi 0,012<0,05 dan Pendapatan Asli Daerah memiliki nilai $\boldsymbol{t}_{\text {-hitung }}$ sebesar $-1,079<\boldsymbol{t}_{\text {-tabel }}$ sebesar 2,054 dan nilai signifikansi $0,290>0,05$.

Jadi dapat dikemukakan bahwa variabel Dana Alokasi Umum berpengaruh signifikan terhadap Belanja Modal atau $\mathrm{H}_{1}$ diterima karena $\boldsymbol{t}_{\text {-hitung }}>\boldsymbol{t}_{\text {-tabel }}$ dan tingkat signifikansi $<0,05$.

Untuk variabel Pendapatan Asli Daerah tidak berpengaruh signifikan terhadap Belanja Modal, dengan demikian hipotesis $\mathrm{H}_{2}$ ditolak karena $\boldsymbol{t}_{\text {-hitung }}<\boldsymbol{t}$-tabel dan tingkat signifikansi $>$ 0,05 .

\subsection{Pembahasan}

\subsubsection{Pengaruh Dana Alokasi Umum terhadap Belanja Modal}

Hasil pengujian yang telah dilakukan, diperoleh hasil bahwa variabel Dana Alokasi Umum berpengaruh positif dan signifikan terhadap belanja modal. Hal ini ditunjukkan dengan tingkat signifikansi DAU 0,012 $<0,05$ atau Hipotesis 1 diterima. Temuan hasil penelitian ini berarti DAU secara langsung berpengaruh positif signifikan terhadap belanja modal.

\subsubsection{Pengaruh Pendapatan Asli Daerah terhadap Belanja Modal}

Hasil penelitian yang telah dilakukan, diperoleh hasil bahwa ternyata Pendapatan Asli Daerah (PAD) tidak berpengaruh signifikan terhadap belanja modal. Hal ini ditunjukkan dengan tingkat signifikansi PAD 0,290 > 0,05 atau Hipotesis 2 ditolak. Temuan hasil penelitian ini berarti PAD secara langsung tidak berpengaruh positif signifikan terhadap belanja modal.

\subsubsection{Analisis Flypaper effect}

Untuk melihat apakah terjadi flypaper effect pada belanja modal di Kabupaten/Kota Provinsi Maluku Utara, maka dilakukan dengan membandingkan pengaruh Dana Alokasi Umum (DAU) dan Pendapatan Asli Daerah (PAD) terhadap Belanja Modal. Hasil pengujian memperlihatkan fenomena flypaper effect terjadi. Bila diidentifikasi dari belanja modal masing-masing Kabupaten/Kota tahun 2014 sampai 2016 menunjukkan adanya fenomena flypaper effect. Pengujian Regresi menunjukkan bahwa 10 Kabupaten/Kota di Provinsi Maluku Utara pada tahun 2014-2016, DAU memiliki pengaruh besar terhadap belanja modal. Dengan kata lain, bahwa belanja modal ditentukan oleh besaran DAU yang diterima. Dari data yang diperoleh perubahan peningkatan Belanja Modal tidak dipengaruhi oleh peningkatan PAD tapi dipengaruhi oleh perubahan peningkatan yang terjadi pada DAU. Keseluruhan hubungan antara belanja modal dan DAU tersebut adalah positif dan signifikan. Peningkatan DAU akan diikuti oleh peningkatan belanja modal. Hasil ini menguatkan bahwa 
sebenarnya, Kabupaten/Kota di Provinsi Maluku Utara masih menggantungkan belanja modalnya yang bersumber dari DAU. Hasil telah membuktikan besarnya belanja modal pada Kabupaten/Kota di Provinsi Maluku Utara masih lebih besar dipengaruhi oleh dana perimbangan khususnya DAU yang diterima dari pemerintah pusat dibandingkan PAD. Hal ini menunjukkan tingkat ketergantungan fiskal pemerintah daerah terhadap pemerintah pusat masih tinggi. Pemerintah daerah belum dapat sepenuhnya lepas dari pemerintah pusat didalam mengelola keuangan daerah. Pemerintah daerah belum memiliki dukungan PAD dan kurang dalam berinisiasi mengembangkan sumber pendapatan asli daerah sehingga sangat bergantung kepada transfer pemerintah pusat. Dari hasil yang didapat sudah seharusnya pemerintah daerah lebih mengupayakan dan mencari cara untuk memaksimalkan potensi daerahnya dan meningkatkan sumber-sumber daya yang ada sehingga berdampak pada meningkatnya PAD. Bagaimanapun, pemerintah daerah harus segera mandiri dan tidak selalu bergantung pada transfer dari pemerintah pusat. Dengan terjadinya Flypaper Effect dapat dikemukakan bahwa tujuan utama dari pemberian DAU sebagai pemerataan kesejangaan fiskal antar daerah tidak terwujud dan DAU dijadikan sebagai sumber utama daerah untuk pengeluaran daerahnya (Belanja Modal). Sehingga Pemerintah Kabupaten/Kota di Provinsi Maluku Utara harus lebih memaksimalkan potensi daerahnya dan menggunakan sumber daya yang dimiliki secara efektif dan efisien untuk meningkatkan penerimaan Pendapatan Asli Daerah.

\section{KESIMPULAN DAN SARAN}

\subsection{Kesimpulan}

Berdasarkan hasil penelitian dan pembahasan maka peneliti dapat menyimpulkan sebagai berikut:

1. DAU berpengaruh signifikan terhadap Belanja Modal. Kesimpulan ini didasarkan pada hasil analisis data yang menunjukkan bahwa nilai signifikansi menunjukkan angka signifikan dimana nilainya jauh lebih kecil dari taraf signifikansi yang ditolerir. Berarti dengan bukti empiris ini maka jelaslah bahwa DAU berpengaruh positif terhadap Belanja Modal. Hal ini juga berarti bahwa semakin tinggi DAU yang diterima dari pemerintah pusat maka akan berakibat semakin besar terhadap Belanja Modal Kabupaten/Kota di Provinsi Maluku Utara.

2. PAD tidak berpengaruh signifikan terhadap Belanja Modal. Kesimpulan ini didasarkan pada hasil analisis data yang menunjukkan bahwa nilai signifikansi tidak signifikan dimana nilainya lebih besar dari taraf signifikansi yang ditolerir. Artinya peningkatan Belanja Modal Kabupaten/Kota di Provinsi Maluku Utara tidak mengikuti peningkatan yang terjadi pada PAD.

3. Dari hasil pengujian tampak bahwa hanya DAU yang berpengaruh signifikan terhadap Belanja Modal sedangkan PAD tidak berpengaruh signifikan. Berdasarkan hal tersebut maka dapat dikatakan telah terjadi flypaper effect pada Belanja Modal Kabupaten/Kota di Provinsi Maluku Utara.

\subsection{Saran} berikut:

Adapun saran yang dapat diberikan peneliti dalam penelitian ini adalah sebagai

1. Pemerintah Daerah diharapkan bisa untuk lebih memperhatikan potensi sumber daya yang terdapat di daerah masing-masing sehingga dapat mengurangi ketergantungan pada transfer dari Pemerintah Pusat. Flypaper Effect yang telah terjadi menjadi bukti bahwa transfer Dana Alokasi Umum lebih menjadi sumber penerimaan utama daripada sumber Pendapatan Asli Daerah.

2. Bagi pemerintah daerah sebaiknya melakukan perencanaan yang tepat dalam menyusun anggaran belanjanya. Semua pendapatan yang diperoleh pemerintah daerah baik yang 
berasal dari DAU ataupun PAD harus dapat digunakan dengan tepat dan kena tujuannya sehingga dapat menjamin kesejahteraan masyarakatnya dan terpenuhi apa yang menjadi kebutuhan daerah atau masyarakat.

3. Untuk penelitian selanjutnya disarankan agar memperluas variabel-variabel independen (selain DAU dan PAD) misalnya total Dana Perimbangan, Dana Alokasi Khusus, lainlain pendapatan yang sah, dan lain-lain.

\section{DAFTAR PUSTAKA}

Abdullah, Sukriy dan Halim, Abdul. 2003. Pengaruh Dana Alokasi Umum (DAU) dan Pendapatan Asli Daerah (PAD) terhadap Belanja Pemerintah Daerah Studi Kasus Kabupaten/Kota di Jawa dan Bali. Simposium Nasional Akuntansi VI, Yogyakarta

Ghozali, Imam. 2016. Aplikasi Analisis Multivariate dengan program IBM SPSS 23. Edisi:8, Semarang : Badan Penerbit Universitas Diponegoro.

Kusumadewi, D.A., dan A. Rahman. 2007. Flypaper Effect Pada Dana Alokasi Umum (DAU) Dan Pendapatn Asli Daerah (PAD) Terhadap Belanja Daerah (BD) Pada Kabupaten / Kota di Indonesia. JAAI 11(1): 67-80.

Kurnia, E. Daddy. 2013. Analisis Flypaper Effect berdasarkan pemetaan indeks kemampuan keuangan \& pertumbuhan ekonomi di Jawa Timur. Jurnal Ilmiah. Universitas Brawijaya. 2013.

Maimunah, Mutiara. 2006. Flypaper Effect pada Dana Alokasi Umum (DAU) dan Pendapatan Asli Daerah (PAD) terhadap Belanja Daerah pada Kabupaten/Kota di Pulau Sumatera. SNA IX, Padang 23-26 Agustus 2006

Mahsun. 2015. Akuntansi Sektor Publik. Edisi kelima. Yogyakarta: BPFE

Oates, Wallace. (1999). An essay on fiscal federalism. Journal of Economic Literature 37: $1120-1149$.

Peraturan Pemerintah Republik Indonesia Nomor 55 Tahun 2005 Tentang Dana Perimbangan.

Peraturan Menteri Keuangan Nomor 91/PMK.05/2007 tentang Bagan Akun Standar.

Sadeli, Lili M. 2015. Accounting Theory. Edisi 5, Salemba Empat, Jakarta

Siregar, B., 2017, Akuntansi Sektor Publik (Akuntansi Keuangan Pemerintah Daerah Berbasis Akrual, edisi ke-2, Yogyakarta, UPP STIM YKPN

Sumarsan, Thomas. 2013. “Akuntansi Dasar dan Aplikasi dalam Bisnis Versi IFRS”. Jakarta: Indeks

Sugiyono. 2016. Metode Penelitian Kuantitatif, Kuantitatif dan R\&D. Bandung: PT. Alfabet. Undang-Undang Nomor 33 Tahun 2004 Tentang Perimbangan Keuangan Antara Pemerintah Pusat dan Pemerintah Daerah.

Undang-Undang Nomor 32 Tahun 2004 Tentang Pemerintahan Daerah. 